Araştırma Makalesi - Research Article

\title{
Bireysel Emeklilik Firma Yöneticileri Perspektifinden Bireysel Emeklilik Okuryazarlığı ${ }^{1}$
}

\section{Individual Pension Literacy from the Perspectives of Individual Pension Company Managers}

\author{
Seyfettin ÜNAL * \\ (iD) 0000-0002-6248-4317 \\ Nihat GÜL** \\ (iD) 0000-0002-4770-8845
}

Sosyal Güvenlik Dergisi / Journal of Social Security

Cilt: 11 Sayı: 1 Yıl: 2021 / Volume: 11 Issue: 1 Year: 2021

Sayfa Aralı̆̆ı: 1-16 / Pages:1-16

DOI: $10.32331 /$ sgd.952353

\section{ÖZ}

Çalışmayla, ülkemizde bireysel emeklilik okuryazarlı̆ııın mevcut durumunu ortaya koymak amaçlanmıştır. Bireysel emeklilik okuryazarlığı halihazırda ülkemiz literatüründe pek fazla bilinmeyen ve incelenmeyen bir kavramdır. Buna yönelik olarak, mülakat yöntemi kullanılarak sektördeki altı büyük bireysel emeklilik șirketinin bölge müdürlüklerindeki üst düzey yöneticilerle görüş̧meler gerçekleştirilmiştir. Böylece, onların perspektifinden bireysel emeklilik okuryazarlığının ülkemizdeki mevcut durumu ortaya konulmuş; katılımcilara ve çalışanlara yönelik olarak bireysel emeklilik sistemi (BES) konusunda yürüttükleri bilgilendirme ve eğitim çalş̧maları değerlendirilmiştir. Buradan hareketle, bireysel emeklilik okuryazarlığ kavramının oluşturulmasının sisteme sunabileceği faydaların yanı sıra, konunun geliştirilmesine yönelik öneriler incelenmiştir. Çalışma sonucunda, "bireysel emeklilik okuryazarlı̆̆ı" kavramı oluşturulmasının hem bireylere hem bireysel emeklilik şirketlerine ve hem de akademik literatüre önemli katkılar sağlayabileceği sonucuna ulaşılmışstır. Ayrıca, "bireysel emeklilik okuryazarlığı" kavramının oluşturulmasının, sisteme olan katılım, ilgi ve güvenin artmasina ve en nihayet, bunun sonucunda da bireysel emeklilik sisteminin gelişmesine önemli katkılar sunabileceği değerlendirilmektedir.

Anahtar Sözcükler: Bireysel emeklilik okuryazarlığı, finansal okuryazarlık, bireysel emeklilik sistemi

\section{ABSTRACT}

In this study, it is aimed to provide an assessment of the current state of individual pension literacy in Turkey. This concept is not well known in Turkish literature at present. For the purpose, interview method is applied to conduct meetings with six pension companies' senior managers at regional management divisions. Therefore, their perspectives helped revealing the current outlook of the individual pension literacy in Turkey. In addition, it is examined to identify what the pension companies' have to offer both participants and employees within the concept of providing necessary information and training on the individual pension system. Moreover, benefits provided by developing the concept of "individual pension literacy", and suggestions for its enhancements are evaluated. The results show that the constitution of "individual pension literacy" concept is expected to make significant contribution to individuals, pension companies and academic literature. It is also foreseen that this would bring along an increased interest, participation and confidence to the system thus will result in an improved individual pension system eventually.

Keywords: Individual pension literacy, financial literacy, individual pension system

Önerilen atıf şekli: Ünal, S. ve Gül, N. (2021). Bireysel Emeklilik Firma Yöneticileri Perspektifinden Bireysel

Emeklilik Okuryazarlığı. Sosyal Güvenlik Dergisi (Journal of Social Security). 11(1). 1-16

• Geliş Tarihi/Received: 19/03/2021 • Güncelleme Tarihi/Revised: 26/04/2021 • Kabul Tarihi/Accepted: 14/06/2021

\footnotetext{
${ }^{1}$ Bu çalışma Dumlupınar Üniversitesi; Sosyal Bilimler Enstitüsünde 2018 yılında kabul edilen aynı adlı yüksek lisans tezinden üretilmiştir.

* Prof. Dr. Dumlupınar Üniversitesi, İktisadi İdari Bilimler Fakültesi, İşletme Bölümü, seyfettin.unal@dpu.edu.tr

** Finans Bilim Uzmanı, Kütahya Dumlupınar Üniversitesi, Sosyal Bilimler Enstitüsü, nihat.gl.52@gmail.com
} 


\section{GİRIŞ}

Bireyler sosyo-ekonomik anlamda refahlarını artırmak amacıyla, hayatlarının en değerli dönemini oluşturan çalışma hayatlarını olabildiğince verimli değerlendirip, finansal açıdan refaha ulaşmayı hedeflemekte ve genellikle belli ölçüde de bunu başarmaktadır. Doğal olarak, aktif çalışma döneminde elde edilen refah düzeyinin emeklilik döneminde de korunması istenir. Zorunlu sosyal güvenlik sistemi, başta sağlı güvencesi olmak üzere, sunduğu diğer hizmetlerin yanında, aktif çalışma hayatı sonrasına yönelik olarak bireylerin söz konusu beklentilerini karşılamaya çalışmaktadır. Fakat hemen her ülkede var olan sosyal güvenlik sistemi bu beklentileri karşılamakta yetersiz kalmaktadır. Dolayısıyla, isteğe bağlı bireysel emeklilik sistemi, emeklilik döneminde hayat standardının korunmasında, sosyal güvenlik sisteminin tamamlayıcısı olarak yerini almaktadır.

Bireysel emeklilik ülkemizde 2003 yılında ilk emeklilik planlarının onaylanması ile başlamıştır. Sistemin temel amacı bireyleri tasarrufa yönlendirerek, emeklilik döneminde rahat bir yaşam sürmeleri için tamamlayıcı bir rol üstlenip, hayat standartlarını korumalarına yardımcı olmaktır. Bireysel emeklilik sisteminde bireyler, kendi seçtikleri bir emeklilik şirketi ile sözleşme yaparak tasarruflarını katkı payı adı altında sisteme yatırmakta olup; ayrıca, yatırılan katkı payı üzerinden $\% 25$ oranında devlet katkısı hesaplanmakta ve tutar devlet tarafından katılımcıların hesaplarına aktarılmaktadır. Bireyler sistemde 10 yıl kalıp 56 yaşını doldurduktan sonra emekliliğe hak kazanmaktadır. Emeklilik hakkının kazanılması ile birlikte, sisteme yatırılan katkı payları toplu olarak ya da en az on yıllık gelir sigortası sözleşmesi yapılarak maaş şeklinde alınabilmektedir. Dolayısıyla, bireysel emeklilik sistemi vasıtasıyla, emeklilik döneminde destekleyici bir gelir elde edilmektedir. Elbette bireysel emeklilik sisteminin (BES), katılımcısı olan bireylere sağladığı söz konusu faydaların yanında, makroekonomik faydaları da bir hayli fazladır. Hatta doğrudan ve dolaylı olmak üzere çok yönlü makroekonomik katkıların, bireylere sunduğu imkânların çok daha ötesinde olduğu dahi iddia edilebilir. Öyle ki, sermaye piyasasının büyüyüp gelişmesi sayesinde derinliğinin artmasıyla sermayenin tabana yayılmasını kolaylaştıracaktır. Böylece, artan etkinlikle birlikte; ekonominin kıt kaynaklarından olan sermayenin daha düşük maliyetle fonlama imkânı vermesi mümkün olabilecektir. $\mathrm{Bu}$ ise, özellikle finansman maliyetleri yüksek olan ülkemizde, üretim maliyetlerinin haliyle enflasyonun düşmesine kadar uzanan dışsallıklar yaratması sonucunu doğurabilecektir. Büyüyen fon havuzu sayesinde özel sektör ve bireylerin yanı sıra sürekli borçlanma ihtiyacı duyan kamunun finansman maliyetlerinin düşmesi beklenebilecektir. Bunlara ilave olarak, ağır bir yük altında zorlanan sosyal güvenlik sisteminin rahatlaması da BES' in yaratması söz konusu olan kayda değer bir diğer fayda olarak sayılabilir.

Ülkemizde BES yeni ve halen gelişmekte olan bir sistemdir. Son dönemde hayata geçirilen otomatik katılım uygulamasına rağmen, sistemin bilinirliği oldukça düşük düzeydedir. Sistemin bilinirliğinin artırılmasında finansal eğitim ve finansal okuryazarlık önemli bir yere sahiptir. Finansal okuryazar bireyler, sahip oldukları finansal bilgiler ışığında çalışma dönemlerinde finansal açıdan elde ettikleri refahı emeklilik döneminde de sürdürmek için emeklilik planları yapmaktadır. Emeklilik döneminde finansal refahı artırmanın en etkili yollarından biri bireysel emeklilik sistemidir. Finansal okuryazar olan bireylerin farkındalıklarının bireysel emeklilik sistemine olan katılım, ilgi ve güveni olumlu yönde etkilemesi beklenebilecektir.

Gerek finansal okuryazarlığın gerekse onun bir bileşeni olarak kabul edilebilecek olan bireysel emeklilik okuryazarlığının geliştirilmesinde kamudan sivil toplum kuruluşlarına kadar farklı kesimlere önemli görevler düşmektedir. Bilindiği kadarıyla, bireysel emeklilik okuryazarlığı kavramının ilk kez öne atıldığı bu çalışmanın sonraki bölümünde, bireysel 
emeklilik sistemi ve ardından bireysel emeklilik okuryazarlığına kısaca değinildikten sonra konuya ilişkin literatüre yer verilmektedir. Uygulamaya yönelik veri ve yöntemin sunulduğu bölümün ardından bulgular sunulmakta olup; çalışma sonuç bölümüyle sonlanmaktadır.

\section{I- BİREYSEL EMEKLIILIKK SISSTEMİ (BES)}

Bireysel emeklilik sistemi ilk olarak, Amerika Birleşik Devletleri’nde (ABD) 1875 yılında Amerikan Demiryolu Şirketi (The American Express Company) tarafindan kurulmuştur. Sistem Avrupa'da 1940'lı yıllarda yaygınlık kazanmaya başlamıştır (İncidüzen, 2008). Türkiye'de ise, bireysel emeklilik sisteminin hukuki alt yapısı 28.03.2001 tarihinde çıkarılmış olan 4632 sayılı Bireysel Emeklilik Tasarruf ve Yatırım Sistemi Kanunu ile oluşturulmuştur. Çıkarılan bu kanun 7 Ekim 2001 tarihinde yürürlüğe girmiştir. Ancak BES fiilen 27 Ekim 2003 tarihinde ilk emeklilik planlarının onaylanması ile başlamıştır.

Bireyler, bireysel emeklilik sisteminde 10 yıl kalıp 56 yaşını doldurduktan sonra emekliliğe hak kazanmaktadır. Sistem, bireylerin aktif çalışma hayatı sonrasında mevcut refah düzeylerini korumalarını hatta mümkünse daha rahat bir yaşam sürmeleri için ek gelir elde etmelerini sağlayan bir sistemdir. Bireysel emeklilik sistemi, mevcut zorunlu sosyal güvenlik sisteminin tamamlayıcısı olarak; bireylerin elde etmiş oldukları gelirler üzerinden düzenli bir şekilde tasarruf yapmalarını sağlamaktadır. Böylelikle, sahip oldukları refah düzeyinin emekli oldukları dönemde de devamının sağlanması amaçlanmaktadır. Elbette sistemin amacı yalnızca bundan ibaret olmayıp, çok yönlü olduğunu ifade etmek gerekir. Zira sermaye maliyetinin düşürülmesinden sermaye piyasalarının gelişimine; böylelikle, ekonomi için uzun vadeli kaynak oluşturularak, istihdam artsşına kadar uzanan hayli çok sayıda etki alanı ve öneminin olduğu söylenebilir. Bireysel emeklilik sistemi aracıllı̆ıyla tasarrufların özendirilerek bireysel tasarrufların ve böylelikle sermaye birikiminin artırılması, yadsınamayacak makroekonomik faydalar yaratabilmektedir. Örneğin, yukarıda bahsedildiği üzere hayli eski bir dönemde kurulan bireysel emeklilik sisteminin ABD’nin günümüzde sahip olduğu dünyanın en büyük ve gelişmiş sermaye piyasalarına sahip olmasında önemli katkısı olduğu söylenebilir. Zira bireysel emeklilik sisteminde küçük tasarrufların zaman içerisinde birikip büyüyerek ortaya çıkardığı sermaye birikiminin hem sermayenin tabana yayılmasına hem de sermaye piyasalarının derinleşmesine ciddi bir katkı sunması sözkonusudur. Böylelikle, bir taraftan bireylerin daha rahat bir emeklilik dönemi geçirmelerine imkân sağlarken; bir taraftan da gelişmiş sermaye piyasaları sayesinde girişimciliğin önünü açan bir etki yaratması mümkün hale gelmektedir.

\section{II- BİREYSEL EMEKLİLİK OKURYAZARLIĞI}

$\mathrm{Bu}$ çalışmanın oluşumuna katkı vermesi amaçlanan bireysel emeklilik okuryazarlığına ilişkin, literatürde herhangi bir tanıma rastlanmamaktadır. Ancak finansal okuryazarlık tanımından yola çıkılarak, bireysel emeklilik okuryazarlığı için şöyle bir tanımlamaya gidilebilir: “Bireysel emeklilik okuryazarlı̆̆l, bireylerin bireysel emeklilik sisteminin ne olduğu, nasıl işlediği, avantaj ve dezavantajlarının neler olduğu gibi sisteme dair konular hakkında bilgi sahibi olmaları ve bu bilgiler ışı̆̆ında sisteme katılarak emeklilik döneminde finansal refahlarını artırma yetileridir.”

BES'in bilinirliğinin artırılmasında finansal eğitim ve finansal okuryazarlığın önemi oldukça büyüktür. Bireyler, aldıkları finansal eğitimle artan finansal okuryazarlıkları sayesinde, bireysel emeklilik sistemi hakkında da bilgi sahibi olmaktadır. Finansal okuryazarlık artışıyla, bireysel emeklilik sistemine olan ilgi ve güvenin de artması beklenebilecektir. Bireysel emeklilik okuryazarı olan bireylere, aynı zamanda finansal okuryazar da denebilir. Finansal okuryazarlık ile ilgili hazırladığı raporu ABD Başkanına sunan, başkanın finansal okuryazarlık danışma konseyi (PACFL), bireylerin finansal okuryazar olmaları için, 
maddeler halinde sıraladıkları kavramlar hakkında bilgi sahibi olmaları ve bazı yetenekleri taşımaları gerektiğini belirtmiştir. Komitenin belirtmiş olduğu maddeler içerisinde bireysel emeklilik hakkında bilgi sahibi olma ve emeklilik planlaması maddesi de yer almaktadır (Dağdelen, 2017). Bu madde bireysel emekliliğin bilinirliğinin artmasında finansal okuryazarlığın ne kadar önemli olduğunu ve finansal okuryazar bireylerin aynı zamanda bireysel emeklilik okuryazarı da olabileceğini göstermektedir. Ancak bireysel emeklilik okuryazarı olmak için sadece finansal okuryazar olmak yeterli değildir. Çünkü finansal okuryazar olan bireylerin BES ile ilgili bilgi birikimleri sınırlı olabilmektedir. Bu ise, finansal okuryazar olan bireylerin daha düşük bir oranda bireysel emeklilik okuryazarı olduğunu göstermektedir. Bireysel emeklilik okuryazarı olmak, finansal okuryazarlığın yanısıra, bireysel emeklilik sistemine dair geniş bir bilgi birikimine sahip olmayı da gerekli k1lmaktadır.

\section{III- LITERATÜR}

Finansal okuryazarlık kavramı bir hayli yeni olup; tanımı yapılırken tam bir fikir birliğine henüz varılamamıştır. Finansal okuryazarlık kavramı ile ilgili birçok tanım bulunmaktadır. Finansal okuryazarlık konusundaki çalışmaları ile tanınan Lusardi ve Mitchell (2009) finansal okuryazarlığ "finansal planlar yapma, zenginliği inşa etme ve yaşam boyunca sürdürme, borç ve emeklilik gibi konularda doğru ve bilinçli kararlar alma ve ekonomik bilgileri iyi bir şekilde kullanma becerisi" olarak tanımlamaktadır. Finansal eğitim ise, bireylerin finansal karar alım aşamalarında söz konusu kararlarının, bütçelerine uygunluğu ve gereksinimlerini bütünüyle karşılamasına yönelik olarak ihtiyaç duyulan bilgi seviyesine ulaştırılma süreci biçiminde tanımlanabilir. Yapılan tanımlara bakıldığında, bu iki olgunun aslında iç içe geçmiş kavramlar olduğu ortaya çıkmaktadır. Bireyler finansal eğitim almadan finansal okuryazar olamaz. Finansal eğitim bireylerin finansal konularda bilgi, beceri ve davranışlara sahip oldukları süreçtir ve bu süreç finansal okuryazarlıkla sonuçlanmaktadır (Gökmen, 2012).

Bireysel emeklilik sisteminin bilinirliğinin artmasında, finansal okuryazarlık ve finansal eğitimin önemi oldukça büyüktür. Bireylerin almış oldukları finansal eğitim, onların finansal okuryazarlıklarını artırmakta ve finansal okuryazar olan bireyler bireysel emeklilik sistemi hakkında da bilgi sahibi olmaktadır. Finansal okuryazarlık arttıkça bireysel emeklilik sistemine olan ilgi ve güven de artmaya başlamaktadır.

Finansal okuryazarlığın tanımına bakıldığında, finansal okuryazar bireylerin emekliliğe yönelik kararlar aldıkları ve finansal refahlarını sadece çalışma döneminde değil, emeklilik döneminde de devam ettirmeyi amaçladıkları görülmektedir. Bu amaca ulaşmak için en önemli alternatiflerden birisi bireysel emeklilik sistemidir. Finansal okuryazar bireyler bu durumun farkında oldukları için sisteme olan katılım artmaktadır. Bu bağlamda, Özer ve Gürel'in (2014) çalışması, üniversite öğrencilerinin BES bilinirlik düzeylerinin hayli düşük olduğunu gösterir sonuçlar sunmaktadır.

Lusardi ve Mitchell (2009) bireylerin emeklilik planları ve finansal okuryazarlıkları arasındaki etkileşimi incelemeye yönelik olarak yapmış oldukları çalışmalarında, finansal bilgisi (finansal okuryazarlığı) daha yüksek olan bireylerin emeklilik planı yapma olasılıklarının da yüksek olduğunu gözlemlemişlerdir. Finansal okuryazarlık gibi, finansal eğitim de sağlıklı bir emeklilik planlaması yapılması konusunda önemli bir yere sahiptir. Finansal eğitim almış olan bireyler, gerek emeklilik yatırım fonlarının neler olduğuna gerekse içeriklerinin ve kuruluş amaçlarının neler olduğuna dair bilgi sahibi olmaktadır. $\mathrm{Bu}$ bilgiler 1şığında, emeklilik planı yaparken daha sağlıklı kararlar almaktadırlar. Konuya yönelik olarak Altıntaş (2009), belirlenmiş katkı esaslı emeklilik planlarında, katılımcılar için 
finansal eğitim ve yatırım eğitiminin gerekliliğini ortaya çıkarmayı amaçladığı çalışmasının sonucunda, katılımcıların tamamına yakınının emeklilik yatırım fonlarının çeşitleri, içerik ve kuruluş amaçlarının neler olduğu konusunda yeteri kadar bilgi birikimine sahip olmadıklarını gözlemlemiştir. Dolayısıyla, katılımcıların çok düşük bilgi birikimiyle finansal kararlar aldıkları ve hiçbir sorumluluğu olmayan emeklilik aracılarının yönlendirmeleriyle yatırım yaptıkları iddia edilebilir.

Literatürde, özellikle 2008 küresel krizi ile birlikte konuya olan ilginin bir hayli arttığ1 görülmektedir. Finansal ve ekonomik okuryazarlık konularında gerek yabancı gerekse yerli literatürde son dönemde sayıları hızla artan çalışmalar bulunmaktadır. Tablo 1'de finansal okuryazarlık konusuna ilişkin literatürde yer alan çalışmalardan bazıları sunulmaktadır.

Tablo 1. Literatürde Yer Alan Finansal Okuryazarlık Çalışmalarından Bazı Örnekler

\begin{tabular}{|c|c|c|c|c|}
\hline Yıl & Yazar & Yöntem & $\begin{array}{c}\text { Veri Sayısı, } \\
\text { İncelenen Yer }\end{array}$ & Bulgular \\
\hline 2003 & $\begin{array}{c}\text { Beal } \\
\text { Delpachitra }\end{array}$ & $\begin{array}{l}\text { Anket } \\
\text { Yöntemi }\end{array}$ & $\begin{array}{l}\text { Avustralya Southern } \\
\text { Queensland } \\
\text { Üniversitesi (789 } \\
\text { kişi) }\end{array}$ & $\begin{array}{l}\text { Çalışma'da öğrencilerin finansal okuryazarlık } \\
\text { seviyelerinin düşük olduğu ve bu düşüklüğün } \\
\text { liselerde verilen finansal okuryazarlık } \\
\text { eğitimlerinin yetersiz olmasından } \\
\text { kaynaklandığı sonucuna ulaşılmıştır. }\end{array}$ \\
\hline 2006 & $\begin{array}{l}\text { Lusardi ve } \\
\text { Mitchell }\end{array}$ & $\begin{array}{l}\text { Anket } \\
\text { Yöntemi }\end{array}$ & $\begin{array}{c}50 \text { yaş üstü } 1269 \\
\text { kişi }\end{array}$ & $\begin{array}{l}\text { Yaşlı Amerikalılarda finansal cehalet bir hayli } \\
\text { yaygındır. Katılımcıların sadece } \% 19 \text { 'u başarılı } \\
\text { bir emeklilik planlaması yapabilmektedir. }\end{array}$ \\
\hline 2007 & $\begin{array}{c}\text { Lusardi ve } \\
\text { Mitchell }\end{array}$ & $\begin{array}{l}\text { Anket } \\
\text { Yöntemi }\end{array}$ & $\begin{array}{l}\text { 51-56 Yaş } \\
\text { grubundan } 1700 \text { kişi }\end{array}$ & $\begin{array}{l}\text { Finansal eğitimin yanı sıra, bireylere } \\
\text { davranışlarını değiştirebilecekleri araç ve } \\
\text { yöntemler sunulmalıdır. Aşılması gereken } \\
\text { temel zorluk, daha iyi emeklilik planlar } \\
\text { yapmaları ve bunları gerçekleştirebilmeleri için, } \\
\text { hane halklarının ihtiyaç duyduğu finansal } \\
\text { okuryazarlık araçlarıyla donatılmasıdır. }\end{array}$ \\
\hline 2009 & Altıntaş & Başarı Testi & $\begin{array}{l}\text { Ankara (26 } \\
\text { Katılımc1) }\end{array}$ & $\begin{array}{l}\text { Katılımcıların neredeyse hepsinin emeklilik } \\
\text { yatırım fonlarının çeşitleri, içerik ve kuruluş } \\
\text { amaçlarının ne olduğuna dair yeteri kadar bilgi } \\
\text { birikimine sahip olmadıkları gözlemlenmiştir. }\end{array}$ \\
\hline 2013 & Adeleke & $\begin{array}{l}\text { Anket } \\
\text { Yöntemi }\end{array}$ & $\begin{array}{l}\text { Oklahoma State } \\
\text { Üniversitesi (100 } \\
\text { kişi) }\end{array}$ & $\begin{array}{l}\text { Öğrencilerin cinsiyetleri ile finansal } \\
\text { okuryazarlık düzeyi arasında anlamlı bir ilişki } \\
\text { olmadığı ancak öğrencilerin yaşları ve okulda } \\
\text { geçirdikleri yıl ile finansal okuryazarlık düzeyi } \\
\text { arasında anlamlı bir ilişki olduğu ortaya } \\
\text { çıkmıştır. }\end{array}$ \\
\hline 2014 & Bayram & $\begin{array}{l}\text { Basit } \\
\text { Rassal } \\
\text { Örnekleme } \\
\text { Yöntemi }\end{array}$ & $\begin{array}{l}\text { Anadolu } \\
\text { Üniversitesi İIBF, } \\
\text { Porsuk Meslek } \\
\text { Yüksekokulu (600 } \\
\text { kişi) }\end{array}$ & $\begin{array}{l}\text { Finansal eğitim almakta olan İİBF } \\
\text { ögrencilerinin, Porsuk Meslek Yüksekokulu } \\
\text { öğrencilerine nazaran, finansal konularda daha } \\
\text { bilinçli oldukları tespit edilmiştir. }\end{array}$ \\
\hline 2015 & $\begin{array}{l}\text { Çelikkol } \\
\text { Çelikkol }\end{array}$ & $\begin{array}{l}\text { Anket } \\
\text { Yöntemi }\end{array}$ & $\begin{array}{l}\text { Dumlupınar } \\
\text { Üniversitesi Sosyal } \\
\text { Bilimler Meslek } \\
\text { Yüksek Okulu (1870 } \\
\text { kişi) }\end{array}$ & $\begin{array}{l}\text { Ankete katılan kız öğrencilerin finansal } \\
\text { okuryazarlık düzeylerinin, erkek öğrencilere } \\
\text { göre daha yüksek olduğu ortaya çıkmıştır. } \\
\text { Ayrıca Bankacılık ve Sigortacılık, Dış Ticaret } \\
\text { ve Muhasebe ve Vergi programlarında öğrenim } \\
\text { gören öğrencilerin finansal okuryazarlık } \\
\text { düzeylerinin, diğer programlarda öğrenim } \\
\text { gören öğrencilere göre daha yüksek olduğu } \\
\text { sonucuna varılmıștır. }\end{array}$ \\
\hline
\end{tabular}


Tablo 1. Literatürde Yer Alan Finansal Okuryazarlık Çalışmalarından Bazı Örnekler (Devamı)

\begin{tabular}{|c|c|c|c|c|}
\hline Yll & Yazar & Yöntem & $\begin{array}{l}\text { Veri Sayısı, } \\
\text { İncelenen Yer }\end{array}$ & Bulgular \\
\hline 2015 & $\begin{array}{l}\text { Gutnu ve } \\
\text { Cihangir }\end{array}$ & $\begin{array}{c}\text { Anket } \\
\text { Yöntemi }\end{array}$ & $\begin{array}{l}\text { Osmaniye Korkut } \\
\text { Ata Üniversitesi } \\
\text { (144 kişi) }\end{array}$ & $\begin{array}{l}\text { Katılımcıların } \% 84,7 \text { 'sinin Türkiye ve } \\
\text { dünyadaki finansal ve ekonomik her türlü } \\
\text { gelişmeyle ilgilendikleri tespit edilmiştir. }\end{array}$ \\
\hline 2017 & $\begin{array}{l}\text { Başarır } \\
\text { Sarıhan }\end{array}$ & $\begin{array}{l}\text { Anket } \\
\text { Yöntemi }\end{array}$ & $\begin{array}{l}\text { Bandırma On yedi } \\
\text { Eylül Üniversitesi } \\
\quad \text { (407 kişi) }\end{array}$ & $\begin{array}{l}\text { Öğrencilerin finansal okuryazarlık seviyelerinin } \\
\% 58 \text { olduğu tespit edilmiştir. Yaş, cinsiyet gibi } \\
\text { demografik faktörlerin yanı sıra finansal } \\
\text { sisteme katılım konusunda öğrencilerin finansal } \\
\text { okuryazarlık seviyelerinde farklılık olduğu } \\
\text { ortaya çıkmıştır. }\end{array}$ \\
\hline 2017 & $\begin{array}{l}\text { Çelikkol } \\
\text { Çelikkol } \\
\text { Özkan }\end{array}$ & $\begin{array}{c}\text { Anket } \\
\text { Yöntemi }\end{array}$ & $\begin{array}{l}\text { Dumlupınar } \\
\text { Üniversitesi (505 } \\
\text { kişi) }\end{array}$ & $\begin{array}{l}\text { Araştırmada bağımlı bir değişken olarak kabul } \\
\text { edilen "Kendinizi finansal okuryazar olarak mı } \\
\text { tanımlarsınız?" sorusuna akademik personelin } \\
117 \text { 'sinin }(\% 23,2) \text { "Evet”, 388'inin (\%76,8) ise } \\
\text { "Hayır" olarak yanıt verdiği ortaya çıkmıştır. } \\
\text { Ortaya çıkan sonuca göre, araştırmaya katılmış } \\
\text { olan } 505 \text { akademik personelin \% 76.8'i } \\
\text { kendilerini finansal okuryazar olarak } \\
\text { tanımlamamıştır. Ancak yapılan analiz } \\
\text { doğrultusunda kendisini finansal okuryazar } \\
\text { olarak tanımlayan akademik personelin 51'inin } \\
\text { finansal okuryazar olarak kabul edilemeyeceği } \\
\text { ve kendisini finansal okuryazar olarak } \\
\text { tanımlamayan akademik personelin 24'ünün } \\
\text { aslında finansal okuryazar olarak } \\
\text { değerlendirilebileceği sonucuna varılmıstır }\end{array}$ \\
\hline
\end{tabular}

Gelişmiş ekonomilere kıyasla, ülkemizde hali hazırda bireysel emeklilik sisteminin bizzat kendisi bir hayli yenidir. Bununla birlikte, özellikle devlet katkısı ve sisteme yönelik gerek işleyiş gerekse denetim ve gözetim bağlamında, şeffaflık ve güveni artırıcı yasal altyapı sayesinde; sistem hızlı bir büyüme sergilemiştir. Bu durum konuya ilişkin akademik çalışmaların da artmasını beraberinde getirmiştir. Tablo 2'de bireysel emeklilik sistemine yönelik literatürde yer alan çalışmalardan bazıları sunulmaktadır.

Tablo 2. Literatürde Yer Alan Bireysel Emeklilik Çalışmalardan Bazı Örnekler

\begin{tabular}{|c|c|c|c|c|}
\hline Yıl & Yazar & Yöntem & $\begin{array}{l}\text { Veri Sayısı, } \\
\text { İncelenen Yer }\end{array}$ & Bulgular \\
\hline 2010 & $\begin{array}{c}\text { Şener ve } \\
\text { Akın }\end{array}$ & $\begin{array}{l}\text { Anket } \\
\text { Yöntemi }\end{array}$ & $\begin{array}{l}\text { Farklı meslek, } \\
\text { eğitim ve yaş } \\
\text { gruplarından } 400 \\
\text { kişi }\end{array}$ & $\begin{array}{l}\text { Bireylerin eğitim ve gelir düzeyleri yükseldikçe } \\
\text { sisteme katılmaya meyilli oldukları } \\
\text { gözlemlenmiştir. }\end{array}$ \\
\hline 2012 & Uyar & $\begin{array}{c}\text { Riske } \\
\text { Maruz } \\
\text { Değer- } \\
\text { VAR } \\
\text { Modelleri }\end{array}$ & $\begin{array}{l}\text { EGM, TCMB ve } \\
\text { TUİK 2004/2009 } \\
\text { Verileri }\end{array}$ & $\begin{array}{l}\text { Çalışma sonucunda, yalnızca sertifika sayısı ile } \\
\text { mevduat faizi arasında anlamlı bir ilişki olduğu } \\
\text { tespit edilmiştir. }\end{array}$ \\
\hline 2012 & $\begin{array}{l}\text { Özer ve } \\
\text { Çinar }\end{array}$ & $\begin{array}{l}\text { Anket } \\
\text { Yöntemi }\end{array}$ & $\begin{array}{l}\text { Bir Vakıf } \\
\text { Üniversitesi (112 } \\
\text { kişi) }\end{array}$ & $\begin{array}{l}\text { Vakıf üniversitesindeki akademik personele } \\
\text { ilişkin cinsiyet, yaş, gelir düzeyi ve çalışma yılı } \\
\text { gibi değişkenlerle BES'e bakış açıları arasında } \\
\text { anlamlı bir ilişki olduğu ortaya çımıştır. }\end{array}$ \\
\hline
\end{tabular}


Bireysel Emeklilik Firma Yöneticileri Perspektifinden Bireysel Emeklilik Okuryazarlı̆̆1

Tablo 2. Literatürde Yer Alan Bireysel Emeklilik Çalışmalardan Bazı Örnekler (Devamı)

\begin{tabular}{|c|c|c|c|c|}
\hline Yll & Yazar & Yöntem & $\begin{array}{l}\text { Veri Sayısı, } \\
\text { İncelenen Yer }\end{array}$ & Bulgular \\
\hline 2014 & $\begin{array}{l}\text { Bayar ve } \\
\text { Kilıç }\end{array}$ & $\begin{array}{c}\text { Betimsel } \\
\text { Analiz }\end{array}$ & $\begin{array}{c}\text { OECD 2001/2011, } \\
\text { EGM 2004/2011 } \\
\text { Verileri }\end{array}$ & $\begin{array}{l}\text { Küresel finansal krizin yaşandığı süre boyunca } \\
\text { emeklilik fonlarının toplam net varlık } \\
\text { değerlerindeki artışın hız kaybederek azaldığı, } \\
\text { ağırlıklı olarak hisse senedi içeren emeklilik } \\
\text { fonlarının negatif bir getiri sağladığı, bu yüzden } \\
\text { portföy seçiminde hisse senedinden tahvile } \\
\text { doğru bir kayma olduğu ve sisteme katılımdaki } \\
\text { artış hızının önemli derecede azalmaya } \\
\text { başladığı sonucuna ulaşılmıştır. }\end{array}$ \\
\hline 2015 & $\begin{array}{l}\text { Sezgin ve } \\
\text { Yildırım }\end{array}$ & $\begin{array}{c}\text { Betimsel } \\
\text { Analiz }\end{array}$ & SGK, EGM Verileri & $\begin{array}{l}\text { Türkiye'de bireysel emeklilik sisteminin } \\
\text { etkinliğini incelemeye yönelik yapmış oldukları } \\
\text { çalışma sonucunda son yıllarda sisteme } \\
\text { katılımın artması ile birlikte farkındalığın da } \\
\text { arttığını ve birçok bireyin bireysel emeklilik } \\
\text { sigortası yaptırmaya başladıklarını } \\
\text { gözlemlemişlerdir. }\end{array}$ \\
\hline 2016 & Kesgingöz & $\begin{array}{c}\text { Betimsel } \\
\text { Analiz }\end{array}$ & $\begin{array}{c}\text { TÜİK 2006/2010 } \\
\text { Verileri }\end{array}$ & $\begin{array}{l}\text { Yaşanan ekonomik krizler sebebiyle } \\
\text { yoksullaşmaya başlayan insanların güvenli bir } \\
\text { gelire sahip olmak, tasarruf yapmak ve sağlık } \\
\text { güvencesi sağlamak için emekli olmayı tercih } \\
\text { ettikleri gözlemlenmiştir. Ayrı emeklilik } \\
\text { yaşının sürekli ileri yaşlara uzaması nedeniyle } \\
\text { bireylerin sosyal güvenlik kurumuna alternatif } \\
\text { olarak bireysel emeklilik sistemine yöneldikleri } \\
\text { ortaya çıkmıştır. }\end{array}$ \\
\hline 2017 & $\begin{array}{l}\text { Çömlekçi } \\
\text { Gökmen }\end{array}$ & $\begin{array}{l}\text { Anket } \\
\text { Yöntemi }\end{array}$ & $\begin{array}{l}\text { TR42 Bölgesi (384 } \\
\text { kişi) }\end{array}$ & $\begin{array}{l}\text { BES'e katılma konusunda gelecek kaygısı, bilgi } \\
\text { düzeyi, uzmanlık düzeyi, yatırım ve güvence } \\
\text { olmak üzere dört farklı faktörün etkili olduğu } \\
\text { ortaya çıkmıştır. Bununla birlikte yapılan faktör } \\
\text { analizi sonucunda ortaya çıan tüm boyutlar ile } \\
\text { bireylerin demografik özellikleri arasında } \\
\text { anlamlı farklılıkların olduğu ortaya çıkmıştır. }\end{array}$ \\
\hline 2019 & $\begin{array}{c}\text { Ünal, Boz } \\
\text { ve Ateşer } \\
\text { (2019) }\end{array}$ & $\begin{array}{l}\text { Anket } \\
\text { Yöntemi }\end{array}$ & $\begin{array}{c}\text { Kütahya’daki Banka } \\
\text { Çalışanları (120 } \\
\text { kişi) }\end{array}$ & $\begin{array}{l}\text { Banka çalışanlarının finansal okuryazarlık } \\
\text { düzeyinin yüksek olduğu; finansal okuryazarlık } \\
\text { düzeyinin yaş, eğitim, iş tecrübesi ve BES } \\
\text { üyeliğine göre farklılı gösterdiği tespit } \\
\text { edilmiştir. }\end{array}$ \\
\hline 2020 & $\begin{array}{l}\text { Canöz ve } \\
\text { Baş (2020) }\end{array}$ & $\begin{array}{l}\text { Anket } \\
\text { Yöntemi }\end{array}$ & $\begin{array}{l}\text { Devlet ve vakıf } \\
\text { üniversite } \\
\text { akademisyenleri } \\
\text { (405 kişi) }\end{array}$ & $\begin{array}{l}\text { Devlet üniversitesi akademisyenlerinde BES’e } \\
\text { giriş kararını etkileyen faktörler tasarruf ve } \\
\text { yatırım alışkanlığı, finansal okuryazarlık } \\
\text { düzeyi, gelecek kaygısı, cinsiyet ve görev süresi } \\
\text { iken; vakıf üniversitesi akademisyenlerinde } \\
\text { etkili faktörler ise, tasarruf ve yatırım } \\
\text { alışkanlığı, finansal okuryazarlı düzeyi ve } \\
\text { yaştır. }\end{array}$ \\
\hline
\end{tabular}

Literatürde yer alan bu çalışmalar incelendiğinde, her iki konu üzerinde hem farklı hem de benzer birçok çalışma yapıldığı görülmektedir. Her ne kadar farklı ve benzer birçok çalışma yapılmış olsa da bu iki konuyu birlikte ele alan çalışma sayısı oldukça azdır. Literatürde, bireysel emeklilik ve finansal okuryazarlık konularının etkileşiminden yola çıkarak oluşturulmakta olan bireysel emeklilik okuryazarlığı konusuna dair çalışma sayısı yok denecek kadar azdır. 


\section{IV- VERI VE YÖNTEM}

Araştırmada nitel bir analiz yöntemi olma özelliği taşıyan derinlemesine mülakat türlerinden biri olan, yarı-yapılandırılmış mülakat yöntemi kullanılmıştır. Derinlemesine mülakat, araştırılmakta olan konuyu tümüyle ele alan, çoğunlukla açık uçlu soruların yöneltildiği ve cevapların kapsamlı bir şekilde alınmasını sağlayan, yüz yüze görüşülerek gereken bilgilerin toplanmasına olanak veren bir veri toplama yöntemidir (Tekin, 2006). Derinlemesine mülakat türlerinden biri olan yarı-yapılandırılmış mülakat ise, hem sabit seçenekli cevap vermeyi hem de konuyla ilgili derinlemesine gitmeyi birleştiren bir yöntemdir (Büyüköztürk vd., 2015). Çalışmada, derinlemesine mülakat yöntemine kaynaklık eden ucu açık 12 adet soru hazırlanmıştır. Soruların cevapları betimsel analizle yorumlanmıştır. Özdemir (2010) betimsel analizi, türlü veri toplama teknikleri vasıtasıyla oluşturulmuş verilerin, araştırmacı tarafından önceden belirlenmiş olan temalara uygun olarak özetlenmesi ve yorumlanmasına dayalı bir nitel analiz türü olarak ifade etmektedir.

Araştırmada yürütülen mülakatlar randevu almak suretiyle, altı farklı bireysel emeklilik şirketinin bölge müdürü ya da müdür yardımcısı düzeyindeki yöneticilerine 2018 yılında uygulanmıştır. Araştırmada örnekleme yöntemi olarak amaçlı (yargısal) örnekleme yöntemi kullanılmıştır. Amaçlı örneklemede araştırmacı, seçilecek kişiler hakkında kendi yargısını kullanır ve yapılacak olan araştırmanın amacına yönelik en uygun olan kişileri örnekleme alır (Balcı, 2006). Araştırmanın örneklemi, altı şirket yöneticisinden oluşmaktadır. Araştırmaya katılan yöneticilerin görev yaptıkları bireysel emeklilik şirketleri, Aegon Emeklilik ve Hayat AŞ., Allianz Hayat ve Emeklilik AŞ., Anadolu Hayat ve Emeklilik AŞ., Avivasa Emeklilik ve Hayat AŞ., BNP Paribas Cardif Emeklilik AŞ., Vakıf Emeklilik AŞ.' dir. Katılımcıların görev yaptığı söz konusu firmaların toplam fon büyüklüğü, sektör toplamının \%62'sini temsil etmektedir. Şirket isimleri yukarıda alfabetik olarak verilmiş olup; şirketlerin gizlilik politikası gereği, katılımcıların sorulara vermiş oldukları cevaplar, firma ismi belirtmeksizin ve yukarıdakinden farklı bir sırada sunulmuştur.

\section{V-BULGULAR}

Mülakat katılımcılarına, bireysel emeklilik okuryazarlığına dair bakış açılarının ne olduğu, katılımcılara ve çalışanlara BES ile alakalı ne tür bilgi ve eğitimler verdikleri, bireysel emeklilik okuryazarlığı kavramı oluşturulmasının bireylere, bireysel emeklilik şirketlerine, sektöre ve akademik literatüre sağlayabileceği katkılar gibi konulara yönelik olarak on iki soru yöneltilmiştir. Her ne kadar soru sayısı on iki olarak ifade edilmiş olsa da bazı sorular kendi içinde birbiriyle bağlantı birkaç sorudan oluşmaktadır. Yapılan bu çalışma nicel bir çalışma olmadı̆̆ından, sayısal verilere dayanmamaktadır. Dolayısıyla, yöneltilen soruların bazılarının cevaplarında yer alan yüzdesel ifadeler, katılımcıların deneyim ve gözlemlerine bağlı olarak sundukları tahmini değerlerdir.

Mülakat katılımcılarına ilk olarak "Bireysel emeklilik sisteminin ekonomik unsurlara katkıları nelerdir?" sorusu yöneltilmiştir. Katılımcıların vermiş oldukları cevaplarda, bireysel emeklilik sisteminden beklenen hem makro ve mikro hem de doğrudan ve dolaylı ekonomik katkıların ön plana çıktığı görülmektedir. Özetle, bireysel tasarrufların teşviki, kamunun uzun vadeli borç yükünün azaltılması, ekonomik gelişmeye katkı sağlaması ve hatta cari açığın düşüşüne kadar uzanan faydalara işaret edilmektedir.

İkinci olarak mülakat katılımcılarına "Finansal okuryazarlığın BES'e katkıları nelerdir?" sorusu yöneltilmiştir. Verilen cevaplarda, tüm katılımcıların finansal okuryazarlığın BES'e olan katkısı konusunda hemfikir oldukları görülmektedir. İletilen ortak görüşler; finansal okuryazar olan tüketicilerin bireysel emeklilik planlarını daha rasyonel ve efektif yönetebildiğine, finansal okuryazarlığın gelişiminin bireylerin sisteme olan güvenlerinin 
artmasına katkı sağladığına işaret etmektedir. Ayrıca, finansal okuryazarlıktaki yükselişin BES'in bilinirliğini artırarak, BES'in kendiliğinden satışını artırdığı görüşü ön plana çıkmaktadır.

Finansal okuryazarlık ve bireysel emeklilik okuryazarlığı arasındaki etkileşim ve ayrımı ortaya koymaya yönelik olarak, katılımcılara yöneltilen üçüncü soru "Finansal okuryazar olan bireylerin ne ölçüde bireysel emeklilik okuryazart olduğunu düşünüyorsunuz?" sorusudur. Alınan geri dönüşlerde, cevapların oldukça birbirine yakın olduğu görülmektedir. Öyle ki, altı katılımcıdan dördü finansal okuryazar olan bireylerin büyük ölçüde BES okuryazarı olduğunu söylerken; bir diğer katılımcı bu durumu oran vererek belirtmiş ve finansal okuryazar bireylerin \%80 oranında BES okuryazar olduğunu ifade etmektedir. Zira bireysel emeklilik sisteminde yer alan fonların, finansal piyasalarda bulunan yatırım araçlarının bünyesinde işlem gördüğüne dikkat çekilmektedir. Kalan bir katılımcı ise, finansal okuryazarlık düzeyi \%100 olan bir bireyin, bireysel emeklilik okuryazarlık düzeyinin de \%100 olacağını belirtmektedir. Buna göre, maksimum düzeyde finansal okuryazar olan bireyler; mevzuat, sistem ve BES'te yer alan fonlar hakkında da bilgi birikimine sahip olabilmektedir.

Mülakat katılımcılarına dördüncü olarak "Bireysel emeklilik okuryazarlı̆̆l konusunda akademik çalışmalar yapılmasının ne gibi katkılar sunabileceğini düşünüyorsunuz?”, "Kurumsal anlamda finansal okuryazarlık konusunda ne tür çalışmalar yürütmektesiniz?" soruları yöneltilmiştir. Aynı çatı altında yöneltilen iki sorudan ilkine verilen cevaplarda bir fikir birliğinden söz etmek mümkündür. Özetle katılımcılar, bu alandaki akademik çalışmaların halihazırda yeterli düzeyde olmadığı fakat artacak çalışmaların, bireysel emeklilik sistemi de dâhil olmak üzere tüm finansal sistemi geliştireceğini, akademik literatürün zenginleşmesine, akademik camianın ve bireylerin sisteme olan ilgilerini artıracağını; sisteme katılım ve güveni artırarak, sektörde çalışabilecek bilgili, donanımlı ve nitelikli bireylerin yetişmesine katkı sağlayacağını değerlendirmektedir.

Sorunun ikinci kısmına verilen cevaplarda ise, kurumların farklı kesimlere yönelik ve farklı yaklaşımlarla da olsa, finansal okuryazarlık konusunda kurumsal çabalar gösterdiğine ilişkin ifadelere yer verilmektedir. Örneğin, bir katılımcı, çalışanlarına yönelik finans matematiği ve işletme finansmanı gibi eğitimler verildiğinden bahsederken; bir diğer katılımcı, finansal danışmanlara eğitimler verildiğini belirtmektedir. Katılımcılardan bir diğeri, bireysel yatırımcıların dört farklı segmente ayrılarak, her bir segmentte risk profillerine uygun fon sepeti önerme yoluna gidildiğini ve buna uygun fon yönetimi sağlandığını ifade etmektedir. Katılımcılardan birisi, finansal okuryazarlık gelişimi için reklam ve pazarlama faaliyeti yürütüldüğünü belirtirken; bir diğer katılımcı ise, günlük ve haftalık fon bültenleri yayınlanmak suretiyle yatırımcıların fonlar hakkında doğru bilgi sahibi olmaları ve böylece finansal okuryazarlık artışı sağlanmasının hedeflendiğini beyan etmektedir. Son olarak, bir diğer mülakat katılımcısı ise, bireylerin ücretsiz olarak erişebileceği finansal konularda eğitim veren "Aile Akademisi" oluşturulduğunu; ilköğretim öğrencilerine yönelik olarak MEB ve UNICEF ile birlikte "Sanat Yoluyla Sosyal ve Finansal Eğitim" projesinin hayata geçirildiğini, ayrıca "Bütçemi Yönetebiliyorum Projesi" oluşturularak, Halk Eğitim Merkezleri’nde finansal okuryazarlığı düşük seviyede olan ailelere eğitimler verildiğini ifade etmektedir.

Beşinci olarak, mülakat katılımcılarına "Bireysel emeklilik sistemine yeni katılan bireylere sistemle ilgili ne tür bilgiler vermektesiniz?”, “Bu bilgileri sunarken ne tür yollar izlemektesiniz?” soruları yöneltilmiştir. Genel olarak mülakat katılımcılarının aktarımları benzerlik göstermektedir. Şirketlerin yeni katılımcılara yönelik bilgilendirmelerinde, başta yasal zorunlulukların gereği olan konular ve mevzuata dair temel bilgilerin aktarılması olmak 
üzere; sistemin avantaj ve dezavantajlı yönleri gibi tanıtımların yapıldığı gözlenmektedir. Şirketlerin bilgilendirme yöntemlerinde de bir hayli benzer kanalların kullanıldığı anlaşılmaktadır. Yasal çerçeveyle belirlenmiş olan ve firmaların hepsinde aynı olan yazılı formlar ve sözleşme nüshasının müşteriye tesliminin yanında; diğer basılı görsel materyaller, yüz yüze görüşmeler, telefonla gerçekleştirilen 'hoş geldin' aramaları ve periyodik olarak gönderilen e-postalar aracılığıyla bilgilendirmeler yapılmaktadır. Söz konusu bilgilendirmelerde acente ve şubelerin kullanıldığından da bahsedilmektedir.

BES şirketlerindeki çalışanların bireysel emeklilik okuryazarlığına ilişkin durumlarını tespit etmek üzere, mülakat katılımcılarına altıncı olarak, "Şirketinizde çallşan personelin BES konusunda yeterli bilgi ve tecrübeye sahip olduğunu düşünüyor musunuz?”, "Onların daha iyi bilgi ve tecrübeye sahip olmaları için neler yapıyorsunuz?” soruları yöneltilmiştir. Altı katılımcının tamamı sorunun ilk kısmını “evet”, şeklinde cevaplandırmaktadır. Elbette, söz konusu cevabın "hayır'” olması şaşırtıcı olurdu. Dolayısıyla, katılımcıların devamındaki açıklamalarını dikkatle inceleyerek, teyit edici ipuçları olup olmadığını görmeye çalışmak gerekmektedir. $\mathrm{Bu}$ bağlamda, katılımcıların tamamı eğitim ve sunum ve bilgilendirme toplantılarından bahsetmekle birlikte, spesifik olarak; çalışanlarına, katılımcılardan birisi SPK lisans1, birisi BES lisans1 alma zorunluluğu bulunduğunu ve bu yönde eğitim verdiklerini ifade etmektedir. Bir diğer katılımcı ise, yine spesifik olarak BES lisansıyla çalışan personellerinin sektördeki en düşük sirkülasyon oranına sahip olduğuna vurgu yapmaktadır. Özetle, söz konusu ifadelerde altı mülakat katılımcısından üçünün bu konuda daha net ve teyit edici bilgi sundukları görülmektedir. Son olarak, mülakat katılımcılarının tamamının temsil ettiği şirketlerde, çalışanlara yönelik verilen periyodik, güncelleyici ve dinamik eğitimlerin yanısıra, yukarıda da sözü edildiği üzere, üç firmada lisanslama eğitimleri ön plana çıkmaktadır.

Yedinci olarak mülakat katılımcılarına "Acentelerin BES hakkında bilgi ve tecrübelerinin ne durumda olduğunu ölçmekte misiniz?”, "Ölçüm yapılıyorsa sonuçları hakkında bilgi verebilir misiniz?” soruları yöneltilmiştir. Bu sorulara verilen cevaplar değerlendirildiğinde, yöneticilerden üçünün benzer cevaplar verdiği görülmektedir. Buna göre, söz konusu üç şirkette acentelere eğitimler verildiği ve acentelerin denetimlerinin bağlı oldukları yöneticiler tarafından yürütüldügü ifade edilmektedir. Diğer üç yöneticiden birisi, acentelerin ölçümlendiğini fakat firma gizlilik ilkesi gereği açıklanamayacağını ifade ederken; bir diğer yönetici böyle bir ölçümlemenin bulunmadığını belirtmektedir. Bir diğeri ise, şirkete bağlı acente bulunmadığını açıklamaktadır. Acentesi bulunmayan şirketin yöneticisinin bu soruya ilişkin olarak daha objektif bir değerlendirme yapabileceğinden hareketle, söz konusu yöneticinin değerlendirmesi dikkatlice analiz edilmiştir. Bu bağlamda, ilgili yönetici, sektördeki acentelere yönelik gözlemlerine göre, acentelerin bilgi ve deneyimlerinin sınırlı olduğunu ifade etmektedir.

Acentelerin bireysel emeklilik okuryazarlı̆ğ yetkinliğini ortaya koymak adına, katılımcılara sekizinci olarak, "Acenteler BES'te yatırım yapılacak olan enstrümanların neler olduğu hakkında yeterli bilgiye sahip mi?", "Katılımcılara yatırım yapabilecekleri enstrümanlar hakkında gerekli bilgi verilmekte midir?" soruları yöneltilmiştir. Böylelikle, bir önceki soruya verilen cevapların bir anlamda teyit edilip edilemeyeceğini de ortaya koymak amaçlanmıştır. Yöneticilerin sorulara ilişkin geri dönüşleri değerlendirildiğinde, acente sistemini kullanan beş katılımcı, özellikle acentelere sundukları eğitimleri ön plana çıkartmak suretiyle; acentelerin yeterliliğini ve BES katılımcılarına gerekli bilgileri sağladıklarını ileri sürmektedir. Söz konusu beş yöneticiden birisi, acentelerin de BES katılımcısı olması nedeniyle yeterli bilgi birikimine sahip olduklarına dikkat çekmektedir. Ayrıca, beş yöneticiden bir diğeri ise, bölge müdürlüğ̈ nezdindeki temsilci sayesinde acentelerin ihtiyaç duydukları desteği birebir ve hızlıca alabildiklerinin altını çizmektedir. Acente sistemi ile 
çalışmayan bir katılımcı ise, yedinci soruya cevaben belirttiği üzere, yine dışarıdan gözlemini ortaya koymakta ve acentelerin bilgi birikimlerinin düşük olduğu yönündeki görüşünü tekrar ifade etmektedir.

Yakın dönemde uygulamaya konulan otomatik katılım hakkındaki değerlendirmelerini almak üzere, yöneticilere dokuzuncu olarak, "Otomatik BES hakkındaki düşünceleriniz nelerdir?”, "Bu sistem hakkında çalışanlarınızı ve katılımcılarınızı ne şekilde bilgilendirdiniz?” soruları yöneltilmiştir. Yöneticilerin konuya ilişkin ön plana çıkardıkları belli başlı hususlar şöylece özetlenebilir. Mülakat katılımcılarının tamamı otomatik katılımın gerekli ve faydalı olduğu konusunda görüş birliğinde olup; hatta birisi geç kalındığını, bir diğeri ise normal BES'ten bile avantajlı olduğunu ifade etmektedir. Bununla birlikte, cayma hakkı kullanımının yüksek oranda olması nedeniyle sistemden çıkışların bir hayli fazla olmasının, hedeflenen amaca ulaşma noktasında zafiyet yarattığı ifade edilmektedir. Dolayısıyla, sistemle ilgili düzenlemelerin gözden geçirilmesi gerektiğini ifade eden bir yöneticinin yanı sıra, bir diğer yönetici sistemin zamanla zorunlu hale gelmesi gerektiğini belirtmektedir. Yöneticilerin tamamının, otomatik katılım konusunda gerek çalışanların gerekse katılımcıların bilgilendirildiğini belirtmekle birlikte; sistemin yeterince bilinmediği için çıkışların yüksek olduğunu ifade etmeleri bir çelişkiyi ortaya koymaktadır. Öyle ki, bir yöneticinin, otomatik katılım sistemini bireylere daha iyi anlatabilecek danışmanların ve kalifiye elemanların yetiştirilmesine ihtiyaç olduğunu belirtmesi, aslında mevcut yetersizliği ortaya koyar niteliktedir.

Firma yöneticilerine onuncu olarak, "Ülkemizde bireysel emeklilik hakkında ne tür yenilikler ve çalışmalar yapılmaktadır?", "Yapılan yenilik ve çalışmalar yeterli midir?" soruları yöneltilmiştir. Yöneticilerden alınan cevaplarda, bir yönetici daha çok yasal düzenlemelerin altını çizerken; dört yönetici otomatik katılım ve devlet katkısını ön plana çıkarmaktadır. Bu dört yöneticiden birisi, söz konusu yeniliklerin şirketlerin reklam faaliyetlerinde artış1 beraberinde getirdiğine ve böylelikle sistemdeki fon büyüklügünün arttığına dikkati çekmektedir. Bir yönetici ise, firmaların belirli dönemlerdeki ve belli meslek gruplarına yönelik kampanyalarına vurgu yapmaktadır. Yenilik ve çalışmaların yeterliliği konusunda ise, yöneticilerin görüş birliğinden söz edilebilir. Buna göre, yenilikler desteklenmekte, daha da fazlasının yapılmasının gerekliliğine inanılmakta; yasal düzenlemelerin hem katılımcıların lehine olması gerektiği hem de teşvik edici ve sistemi güçlendirici olması gerektiği ifade edilmektedir.

On birinci soru çatısı altında yöneticilere, "Bireylerin BES hakkında bilgi sahibi olmaları ve bilgi düzeylerinin artırılması yönünde yaptı̆̆ını çalışmalar ne derecede etkili oldu?”, "Çalışmalarınızın bireysel emeklilik okuryazarlığına katkısını yeterli buluyor musunuz?" soruları yöneltilmiştir. Öncelikle belirtmek gerekir ki, mülakata katılan yöneticilerin tamamı kendi kurumları adına, yaptıkları çalışmaları yeterli bulmaktadır. Bu bağlamda yöneticilerin, şirketlerin tanıtım faaliyetlerinin yanı sıra gerek çalışanlarına gerekse sistem katılımcılarına yönelik yürüttükleri eğitim faaliyetlerine dikkat çektikleri görülmektedir. Günümüz iletişim araçları kullanılarak katılımcılara ulaşıldığı ve düzenli olarak bilgilendirmelerin yapıldığg belirtilmektedir. Böylelikle, katılımcıların BES bilgi düzeylerinin yükseldiği ifade edilmektedir. Ayrıca, bir yönetici, katılımcıların bilgilendirilmeleri sayesinde memnuniyetlerinin arttı̆̆ı ve bunun da sistemde kalmalarını sağladığı yönünde değerlendirmede bulunmaktadır. Diğer taraftan, yöneticiler, firmaları adına yeterli gördükleri çabaların, sistemin hedeflerine ulaşmasında tek başına yeterli olmayacağını belirtmektedirler. Bu noktada, sektör tarafından yürütülen çabaların akademik çalışma ve eğitimlerle desteklenmesi gerektiği ifade edilmektedir. 
Mülakat katılımcılarının geleceğe dönük öngörülerini almak adına, kendilerine on ikinci ve son olarak, "Ülkemizde bireylerin BES bilgi düzeyi bir başka ifadeyle bireysel emeklilik okuryazarlığı şu an ne durumdadır ve gelecek dönemlerde sizce ne durumda olacaktır?" sorusu yöneltilmiştir. Bu soruya alınan cevaplar büyük ölçüde paralellik göstermektedir. $\mathrm{Bu}$ bağlamda, yöneticilerden ikisi oran belirterek, halihazırda ülkemizde bireylerin BES okuryazarlık düzeyinin \%30 düzeyinde olduğunu ifade etmiştir. Söz konusu bu iki yöneticiden birisi, firma danışmanları ile iletişim halinde olan katılımcılarda bu oranın $\% 70$ düzeyine ulaştığını da not etmektedir. Yöneticilerden bir diğeri, oran aralığ 1 vermek suretiyle, bireylerin BES bilgi düzeyinin \%30-\%40 seviyesinde olduğunu belirtmektedir. Kalan diğer iki yönetici ise oran belirtmese de ülkemizdeki BES okuryazarlık düzeyinin düşük olduğunu ifade ederek yukarıdaki dört yöneticinin ifadelerini doğrular nitelikte görüş belirtmektedir. Mülakat katılımcılarının, ülkemizdeki BES okuryazarlığının geleceğine yönelik beklentileri de hayli örtüşür niteliktedir. Buna göre, mülakat katılımcılarının tamamı, bireylerin BES bilgi düzeyinin gelecekte artacağını düşünmekte olup; finansal okuryazarlığın artmasıyla birlikte, BES okuryazarlığının da gelişeceğini öngörmektedir.

\section{SONUÇ}

Çalışmada, bireysel emeklilik şirketlerinin bölge müdürlüklerindeki üst yönetim kademesinde yer alan katılımcıların bireysel emeklilik okuryazarlığ 1 konusuna yönelik bakış açılarını, bilgi ve düşüncelerini yansıtmak üzere derinlemesine mülakat yöntemi kullanılmıştır. Mülakat katılımcılarına, konuya ilişkin 12 soru yöneltilmiştir. Bu sorulara ilişkin katılımcıların değerlendirmeleri şu şekilde özetlenebilir:

- Bireysel emeklilik sisteminden beklenen hem makro ve mikro hem de doğrudan ve dolaylı ekonomik katkılar mevcuttur.

- Finansal okuryazar olan tüketiciler bireysel emeklilik planlarını daha rasyonel ve efektif yönetebilmekte olup; finansal okuryazarlığın gelişimi, bireylerin sisteme olan güvenlerinin artmasına katkı sağlamaktadır.

- Finansal okuryazar olan bireyler büyük ölçüde BES okuryazarıdır.

- Bireysel emeklilik okuryazarlığına yönelik akademik çalışmalar halen yeterli düzeyde olmayıp; artan çalışmalar sistemin tüm paydaşlarına katkı sağlayacaktır.

- Şirketler, yeni katılımcılara hem yasal zorunluluk gereği olan konularda hem de ilave bilgilendirmelerde bulunmaktadır.

- Tüm katılımcılar, şirket personelinin BES konusunda bilgi ve deneyimi olduğunu ifade etmekle birlikte; altı katılımcıdan üçünün bunu teyit eder yönde, tatmin edici açıklama sunamadıkları görülmektedir.

- Acentelerin BES'e ilişkin bilgi ve deneyimleri konusunda, acentesi bulunan firmaların yöneticileri acentelerin yeterliliğini iddia etmekle birlikte; acentesi olmayan firma yöneticisinin dişarıdan gözlemi, acentelerin yetkinliği konusunda soru işaretleri olduğunu ortaya koymaktadır.

- Acentelerin BES enstrümanları hakkındaki bilgi düzeyi ve katılımcıları bilgilendirme becerilerine yönelik cevaplarda da bir öncekine benzer şekilde, acentesi bulunan firmaların yöneticileri acentelerin yeterliliğini iddia etmekte iken; acente sistemi olmayan firma yöneticisi ise, bu konudaki olumsuz gözlemini aktarmaktadır. 
- Otomatik katılım önemli ve gereklidir. Fakat sistem hakkındaki bilgilendirme eksikliği nedeniyle cayma hakkı kullanımının yüksek olması, hedeflenen düzeye ulaşılmasını engellemektedir.

- Sisteme yönelik yenilikler desteklenmekte, daha da fazlasının yapılmasının gerekliliğine inanılmaktadır. Yasal düzenlemeler hem katılımcıların lehine olmalı hem de teşvik edici ve sistemi güçlendirici olmalıdır.

- Bireylerin BES hakkında bilgi sahibi olmaları ve bilgi düzeylerinin artırılmasına yönelik olarak, firmaların yeterince çaba gösterdiği fakat sistemin hedeflerine ulaşmasında tek başına yeterli olamayacağı ifade edilmektedir. Söz konusu çabaların akademik çalışma ve eğitimlerle desteklenmesi gerektiğine inanılmaktadır.

- Geleceğe yönelik öngörüler, bireylerin BES bilgi düzeyinin artacağı; finansal okuryazarlığın artmasıyla, BES okuryazarlığının da gelişeceği yönündedir.

Yöneticilerin vermiş oldukları cevaplar değerlendirildiğinde, finansal okuryazarlığın bireysel emeklilik sistemine sağladığı katkılar ön plana çıkmaktadır. Finansal okuryazar olan bireyler, sistemin sağlıklı bir şekilde işlemesine katkıda bulunmakta ve sistemin diğer bireylere doğru bir şekilde anlatılmasına yardımcı olmaktadırlar. Dolayısıyla, finansal okuryazarlığın BES' in bilinirliğinin artırılmasında önemli bir yere sahip olduğu söylenebilir.

Bireysel emeklilik okuryazarlığı kavramının oluşturulmasının, sisteme dair akademik literatürün zenginleşmesine, yazılı kaynakların artmasına ve sektörün sağlıklı bir şekilde gelişmesine önemli katkılar sağlayacağı değerlendirilmektedir. Bu yöndeki çabalar ve konuya ilişkin yürütülecek akademik çalışmalar, bireylerin sistem hakkında daha fazla bilgi sahibi olmalarına, sisteme katılım ve güvenin artmasına ve sistemin sağlıklı bir şekilde işlemesine yardımcı olacaktır. Ayrıca, söz konusu çalışmalar BES'in bilinirliğinin artmasına katkıda bulunacaktır.

Bireysel emeklilik okuryazarlığının gelişmesinin bir diğer önemli katkısı ise, bireysel emeklilik şirketlerinin ihtiyaç duyduğu, sektörde çalışacak nitelikli, bilgili ve donanımlı işgücünün yetişmesi yönünde sağlayacağı faydalardır. Bireysel emeklilik şirketleri sektörde hali hazırda bireysel emeklilik konusunda yeterli bilgi ve donanıma sahip çalışan bulma hususunda zorluk çekmektedir. Şirketler bu ihtiyaçlarını karşılamak için çalışanlarına yönelik olarak işe başladıkları andan itibaren eğitim çalışmaları yürütmektedir. Diğer taraftan, sektör çalışanlarında gözlenen yüksek devir oranı önemli bir sorun olarak görülmektedir. Dolayısıyla, şirketler tarafından yürütülen çalışma ve eğitimlerin yanı sıra, bireysel emeklilik okuryazarlığı konusunda akademik camiada da farkındalık oluşturulmasının, üniversitelerde bu alana yönelik eğitimler verilmesinin ve bireysel emeklilik okuryazarı olan bilgili ve nitelikli uzman çalışanlar yetiştirilmesinin önemi ortaya çıkmaktadır. Bu yönde atılacak adımlarla, hem sektörün ihtiyaç duyduğu yetkin işgücünün yetiştirilmesi hem de bireylerin BES konusunda bilgi sahibi olmaları sağlanabilecektir.

Yöneticilerin mülakatta ortaya koydukları görüşler, bireysel emeklilik okuryazarlığı kavramının oluşturulmasının hem bireylere hem bireysel emeklilik şirketlerine ve hem de akademik literatüre önemli katkılar sağlayacağına işaret etmektedir. Sözkonusu kavram oluşumunun, sisteme olan katılım, ilgi ve güvenin artmasını; dolayısıyla, bireysel emeklilik sisteminin gelişimini desteklemesi beklenebilir. Böylelikle, ülkemiz için çok yönlü ve kritik öneme sahip olan bireysel emeklilik sisteminin gelişip güçlenmesine katkı sağlanmış olacaktır. 


\section{Kaynakça}

Adeleke, T. (2013). The Effects of Gender and Gender Role on the Financial Literacy of College Students. Master of Science Thesis. Graduate College of Oklahoma State University.1-79.

Altıntaş, K. M. (2009). Belirlenmiş Katkı Esaslı Emeklilik Planlarında Finansal Eğitimin Önemi: Katılımciların Finansal Okuryazarlığ Çerçevesinde Alternatif Bir Yatırım Eğitim Modeli. ZKÜ Sosyal Bilimler Dergisi. 5(9). 151176.

Balc1, A. (2006). Sosyal Bilimlerde Araştırma Yöntem, Teknik ve İlkeler. 6. Bask1. Pegem Akademi Yayınc1lık. Ankara.

Başarır, Ç. ve Sarıhan, A. Y. (2017). Üniversite Öğrencilerinin Finansal Okuryazarlıklarının Belirlenmesi: Bandırma Onyedi Eylül Üniversitesi Örneği. Yönetim ve Ekonomi Araştırmaları Dergisi. 15(1). 143-162.

Bayar, Y. ve Kılıç, M. (2014). Küresel Finansal Krizin Türkiye'de Bireysel Emeklilik Sistemine Etkileri. İnsan ve Toplum Bilimleri Araştırmaları Dergisi. 3(2). 246-264.

Bayram, S. S. (2014). Finansal Okuryazarlik ve Para Yönetimi Davranışları: Anadolu Üniversitesi Öğrencileri Üzerine Uygulama. Uluslararası İşletme ve Yönetim Dergisi. 2(2).105-135.

Beal, D. J. and Delpachitra, S. B. (2003). Financial Literacy Among Australian University Students. Economic Papers. 22(1). 65-78.

Büyüköztürk, Ş., Çakmak, E. K., Akgün, Ö. E., Karadeniz, Ş. ve Demirel, F. (2015). Bilimsel Araştırma Yöntemleri. 19. Bask1. Pegem Akademi Yayınları. Ankara.

Canöz, İ. ve Baş, H. (2020). Bireysel Emeklilik Sistemi'ne Giriş Kararlarını Belirleyen Etmenler: Devlet ve Vakıf Üniversitelerinde Çalışan Akademisyenlerin Karşılaştırılması. Sosyal Siyaset Konferansları Dergisi. 78. 361390.

Çelikkol, H., Çelikkol, M. M. ve Özkan, N. (2017). A Research on Financial Literacy of Dumlupinar University's Academic Staff. Manas Journal of Social Studies. 6(4). 447-461.

Çelikkol, M. M. ve Çelikkol, H. (2015). The Evaluation of the Students in Dumlupinar University Vocational School of Social Sciences About Levels of Financial Literacy. Copernican Journal of Finance \& Accounting. 4(2). 43-63.
Çömlekçi, İ. ve Gökmen, O. (2017). Bireysel Emeklilik Sistemine Katılmada Etkili Olan Faktörler: TR42 Bölgesinde Bir Araştırma. Uluslararası Sosyal Araştırmalar Dergisi. 10(49). 579-588.

Dağdelen, T. (2017). Finansal Okuryazarlık Düzeyinin Belirlenmesi ve Aydin Ilindeki Serbest Muhasebeci Mali Müşavirler Üzerine Bir Uygulama. Yüksek Lisans Tezi. Adnan Menderes Üniversitesi. Sosyal Bilimler Enstitüsü, Aydın.

Gökmen, H. (2012). Finansal Okuryazarlık. 1. Baskı. Hiperlink Yayınları. İstanbul.

Gutnu, M. M. ve Cihangir, M. (2015). Finansal Okuryazarlık: Osmaniye Korkut Ata Üniversitesi Personeli Üzerinde Bir Araştırma. Akademik Sosyal Araştırmalar Dergisi. 3(10). 415-424.

İncidüzen, M. A. (2008). Özel Emeklilik Sistemleri ve Türkiye'de Hayat Sigortalarından Bireysel Emeklilik Sistemine Aktarım Süreci. Yüksek Lisans Tezi. Marmara Üniversitesi. Bankacılık ve Sigortacılık Enstitüsü. İstanbul.

Kesgingöz, H. (2016). Türkiye'de Yaşanan 2008 Ekonomik Krizinin Yoksulluk ve Emeklilik Kararları Üzerine Etkisi. Sosyal Güvenlik Dergisi. 6(1). 126-158.

Lusardi, A. ve Mitchell, O. S. (2009). How Ordinary Consumer Make Complex Economic Decisions: Financial Literacy and Retirement Readiness. NBER Working Paper Series. No:15350.1-35.

Lusardi, A. ve Mitchell, O.S. (2007). Financial Literacy and Retirement Preparedness: Evidence and Implications for Financial Education. Business Economics. 42(1). 35-44.

Lusardi, A. ve Mitchell, O. S. (2006). Financial Literacy and Planning: Implications for Retirement Wellbeing. Working Paper, Pension Research Council. Wharton School, University of Pennsylvania.

Özer, A. C. ve Gürel, H. (2014). Türkiye’de Bireysel Emeklilik Sistemi Bilgi Düzeyi ve BES'e Katılımda Devlet Katkısının Etkisi Üzerine Bir Araştırma. Mustafa Kemal Üniversitesi SBE Dergisi. 11(25). 159-166.

Özer, Ö. ve Çınar, E. (2012). Bir Vakıf Üniversitesi Akademik Personelinin Bireysel Emeklilik Sistemine Bakış Açısının Değerlendirilmesi. Mustafa Kemal Üniversitesi Sosyal Bilimler Enstitüsü Dergisi. 9(19). 75-88. 
Özdemir, M. (2010). Nitel Veri Analizi: Sosyal Bilimlerde Yöntembilim Sorunsalı Üzerine Bir Çalışma. Eskişehir Osmangazi Üniversitesi Sosyal Bilimler Dergisi. 11(1). 323-343.

Sezgin, S. ve Yıldırım, T. (2015). Türkiye'de Bireysel Emeklilik Sisteminin Etkinliği. Eskişehir Osmangazi Üniversitesi İ̈BF Dergisi. 10(2). 123-140.

Şener, O. ve Akın, F. (2010). Özel Emeklilik Fonları ve Türkiye'de Bireylerin Bireysel Emeklilik Sistemine Giriş Kararlarını Etkileyen Faktörlerin Belirlenmesi Üzerine Bir Araştırma. Marmara Üniversitesi I.I.I.B.F Dergisi. 28(1). 291-312.

Tekin, H. H. (2006). Nitel Araştırma Yönteminin Bir Veri Toplama Tekniği Olarak Derinlemesine Görüşme. Sosyoloji Dergisi. 3(13). 101-116.

Uyar, H. İ. (2012). Bireysel Emeklilik Sistemi ile Ekonomik Göstergeler Arasındaki İlişkinin İncelenmesi. Mali Çözüm Dergisi. 110. 71-96.

Ünal, S., Boz, D. ve Ateşer, A. (2019). Bireysel Emeklilik Sistemi Üyeliği ve Bazı Demografik Değişkenlerin Finansal Okuryazarlık ile İlişkisi. Sosyal Bilimler Metinleri. 12(2). 104-115. 
